\title{
Indoor Air Quality Prior to and Following School Building Renovation in a Mid-Atlantic School District
}

\author{
Sandra E. Zaeh ${ }^{1,2}$, Kirsten Koehler ${ }^{3}$, Michelle N. Eakin ${ }^{2}$, Christopher Wohn ${ }^{4}$, Ike Diibor ${ }^{4}$, Thomas Eckmann ${ }^{2}$, \\ Tianshi David Wu ${ }^{5,6}$, Dorothy Clemons-Erby ${ }^{3}$, Christine E. Gummerson $^{7}$, Timothy Green ${ }^{3}$, Megan Wood ${ }^{3}$, \\ Ehsan Majd ${ }^{8}$, Marc L. Stein ${ }^{9,10}$, Ana Rule ${ }^{3}$, Meghan F. Davis ${ }^{3,11}$ and Meredith C. McCormack ${ }^{2, *}$
}

\section{check for} updates

Citation: Zaeh, S.E.; Koehler, K.; Eakin, M.N.; Wohn, C.; Diibor, I.; Eckmann, T.; Wu, T.D.; Clemons-Erby, D.; Gummerson, C.E.; Green, T.; et al. Indoor Air Quality Prior to and Following School Building Renovation in a Mid-Atlantic School District. Int. J. Environ. Res. Public Health 2021, 18, 12149. https:// doi.org/10.3390/ijerph182212149

Academic Editor: Paul B. Tchounwou

Received: 17 October 2021

Accepted: 16 November 2021

Published: 19 November 2021

Publisher's Note: MDPI stays neutral with regard to jurisdictional claims in published maps and institutional affiliations.

Copyright: (C) 2021 by the authors Licensee MDPI, Basel, Switzerland. This article is an open access article distributed under the terms and conditions of the Creative Commons Attribution (CC BY) license (https:/ / creativecommons.org/licenses/by/ $4.0 /)$.
1 Division of Pulmonary, Critical Care, and Sleep Medicine, Yale University School of Medicine, New Haven, CT 06510, USA; sandra.zaeh@yale.edu

2 Division of Pulmonary and Critical Care Medicine, Johns Hopkins School of Medicine, Baltimore, MD 21287, USA; meakin1@jhmi.edu (M.N.E.); teckman1@jhmi.edu (T.E.)

3 Department of Environmental Health and Engineering, Johns Hopkins Bloomberg School of Public Health, Baltimore, MD 21287, USA; kkoehle1@jhu.edu (K.K.); dclemo10@jhu.edu (D.C.-E.); tgreen3@jhmi.edu (T.G.); mwood39@jhu.edu (M.W.); arule1@jhu.edu (A.R.); mdavis65@jhu.edu (M.F.D.)

4 Baltimore City Public Schools, Baltimore, MD 21287, USA; crwohn@bcps.k12.md.us (C.W.); idiibor@bcps.k12.md.us (I.D.)

5 Division of Pulmonary, Critical Care, and Sleep Medicine, Baylor College of Medicine, Houston, TX 77030, USA; david.wu@bcm.edu

6 Center for Innovations in Quality, Effectiveness, and Safety, Michael E. DeBakey VA Medical Center, Houston, TX 77030, USA

7 Division of Neurology, Yale University School of Medicine, New Haven, CT 06510, USA; christine.gummerson@yale.edu

8 Division of Mobile Source Control, California Air Resources Board, Sacramento, CA 95817, USA; ehsan.majd@arb.ca.gov

9 Johns Hopkins School of Education, Baltimore, MD 21287, USA; m.stein@jhu.edu

10 Baltimore Education Research Consortium, Baltimore, MD 21287, USA

11 Department of Molecular and Comparative Pathobiology, Johns Hopkins School of Medicine, Baltimore, MD 21287, USA

* Correspondence: mmccor16@jhmi.edu

Abstract: Children spend the majority of their time indoors, and a substantial portion of this time in the school environment. Air pollution has been shown to adversely impact lung development and has effects that extend beyond respiratory health. The goal of this study was to evaluate the indoor environment in public schools in the context of an ongoing urban renovation program to investigate the impact of school building renovation and replacement on indoor air quality. Indoor air quality $\left(\mathrm{CO}_{2}, \mathrm{PM}_{2.5}, \mathrm{CO}\right.$, and temperature) was assessed for two weeks during fall, winter, and spring seasons in 29 urban public schools between December 2015 and March 2020. Seven schools had pre- and post-renovation data available. Linear mixed models were used to examine changes in air quality outcomes by renovation status in the seven schools with pre- and post-renovation data. Prior to renovation, indoor CO measurements were within World Health Organization (WHO) guidelines, and indoor $\mathrm{PM}_{2.5}$ measurements rarely exceeded them. Within the seven schools with pre- and post-renovation data, over $30 \%$ of indoor $\mathrm{CO}_{2}$ measurements and over $50 \%$ of indoor temperatures exceeded recommended guidelines from the American Society of Heating, Refrigerating, and Air Conditioning Engineers. Following renovation, $10 \%$ of indoor $\mathrm{CO}_{2}$ measurements and $28 \%$ of indoor temperatures fell outside of the recommended ranges. Linear mixed models showed significant improvement in $\mathrm{CO}_{2}$, indoor $\mathrm{PM}_{2.5}$, and $\mathrm{CO}$ following school renovation. Even among schools that generally met recommendations on key guidelines, school renovation improved the indoor air quality. Our findings suggest that school renovation may benefit communities of children, particularly those in low-income areas with aging school infrastructure, through improvements in the indoor environment.

Keywords: schools; indoor air quality; renovation 


\section{Introduction}

Americans spend about $90 \%$ of their time indoors, and for children, a substantial portion of this time is spent in the school setting [1]. Indoor air quality is particularly relevant for children. Air pollution has been shown to impact lung growth and contribute to the risk of asthma exacerbation [2], a leading reason for school absences. Studies have linked air quality and thermal comfort to student performance [3-5].

The indoor environment is modifiable and studies have focused on interventions in the home setting as a means to improve the health of children and other household members [6-8]. Interventions in the school environment provide a means to positively impact children at a community level and to benefit many children by interventions focused on shared, common spaces.

As school infrastructure in the United States ages, school buildings require increased maintenance, and school environmental conditions may be less conducive to optimal health and learning. In 2017, nationwide infrastructure reports showed that almost a quarter of public schools with permanent buildings in the United States were rated as being in "fair" or "poor" condition [9]. There are significant disparities in funding for improvement and maintenance of facilities, with prior evidence showing that capital funds for school facility improvement often fail to reach schools with children from low income communities [10].

Prior research from our group has shown that worse school infrastructure is associated with worse student achievement [11]. Additionally, building characteristics within schools such as physical defects (i.e., leaks in roof, broken windows, damaged walls) are associated with increased indoor air pollution (higher indoor $\mathrm{NO}_{2}$ and indoor $\mathrm{CO}$ levels) [12]. Poor air quality can also be a concern during the process of school renovation due to the release of toxic materials during demolition, dust and fumes from construction, and designs that interfere with ventilation [13]. Few studies have directly assessed school environmental conditions and very few have measured the impact of renovation or improvement of school facilities after renovation has been completed [14]. An ongoing school renovation program in an urban environment within the mid-Atlantic region (including the states of Delaware, Maryland, New Jersey, and Pennsylvania) provided the opportunity to apply a natural experimental study design to assess the impact of renovation on indoor air quality. The urban renovation program was launched in 2010 with the aim of addressing the city's aging school buildings and infrastructure [15].

Our aim was to evaluate environmental conditions in schools that were included in the urban renovation program to investigate the impact of school building renovation and replacement on indoor air quality. We hypothesized that school building renovation would lead to improved indoor air quality. We performed a detailed assessment of indoor air quality measures that have been shown to have an impact on health and performance (including $\mathrm{CO}_{2}, \mathrm{PM}_{2.5}, \mathrm{CO}$, and temperature) [16-20].

\section{Methods}

\subsection{School Characterization}

To guide prioritization of schools for renovation, a districtwide facility condition assessment was initially performed by an independent engineering firm (Jacobs Engineering Group, Dallas, TX, USA) [21]. The facility condition index (FCI), a national standard for the overall condition of a building, was calculated for every school [22]. The FCI is derived as a ratio of the cost to repair a given school to the cost of constructing a theoretical school with similar characteristics. FCI $\leq 10 \%$ is good condition; $11-30 \%$ is average; $31-50 \%$ is poor; $51-74 \%$ is very poor; $\geq 75 \%$ is a candidate for replacement [21].

Twenty-nine schools in the ongoing school renovation program were enrolled between December 2015 and March 2020. Institutional review board (IRB) approvals were obtained from the Johns Hopkins School of Public Health IRB and the IRB of the participating school district. Three schools entered the study after renovation had been completed and contributed only post-renovation data, seven schools contributed data pre- and postrenovation, and the remaining nineteen schools contributed only pre-renovation data. 
Within this study, our analysis focuses on the seven schools with both pre- and postrenovation data. Air quality measurements were stopped in March of 2020 due to the COVID-19 pandemic.

\subsection{Renovation}

The renovations performed on each school within the urban renovation program were heterogeneous and tailored to the needs of the individual school. Of the eleven schools in which post-renovation data was assessed, nine schools had additions and substantial renovations performed (including new heating, ventilation, and air conditioning, or HVAC systems, and window replacement) and two schools were replaced [23]. For replacement schools, entirely new school buildings were constructed. One school was constructed at the same site and the other replacement school was constructed behind the existing school. Within the seven schools with pre- and post-renovation data, six schools had renovations performed and one school was replaced. All seven schools had new HVAC systems installed.

\subsection{Procedures for Air Quality Monitoring within Schools}

Within each school, indoor air quality was assessed at three time points within a given academic year. Over 1400 school days of monitoring were performed throughout the study. For most schools, this included a visit in the fall (September to November), winter (December to February), and spring (March to May). Within each season school visit, two weeks of monitoring was performed, with five consecutive days (Monday-Friday) in each week (mean indoor visit length: $89.7 \pm 16.7 \mathrm{~h}$ ). In the first week, one classroom and one common area were monitored, and in the second week, a different classroom and common space were monitored. Common spaces included areas such as the gymnasium, cafeteria, or library. Environmental equipment was placed on a portable table provided by the study team in a protective wire cage/frame with signs that explained the purpose of the equipment. $\mathrm{CO}_{2}$, indoor $\mathrm{PM}_{2.5}, \mathrm{CO}$, and indoor temperature were measured at the same location.

Within monitoring locations, particulate matter with an aerodynamic diameter smaller than $2.5 \mu \mathrm{m}\left(\mathrm{PM}_{2.5}\right)$ was measured using a Personal DataRam (pDR) monitor, model pDR-1200 (Thermo Electron, Franklin, MA, USA), with $0.001-400 \mathrm{mg} / \mathrm{m}^{3}$ concentration measurement range and a 5-min logging resolution. The $\mathrm{pDR}$ was connected to a BGI model $400 \mathrm{~s}$ personal sampling pump (BGI INC., Waltham, MA, USA) operating at the air flow of $4 \mathrm{~L} / \mathrm{min}$, and a BGI model GK 2.05 (Mesa Labs, Butler, NJ, USA) inlet cyclone with a $50 \%$ cut point of $2.5 \mu \mathrm{m}$. Filter samples collected downstream of the pDR nephelometer were collected on 37-mm, $2.0 \mu \mathrm{m}$ pore-size PTFE membrane filters and were used to correct concentrations from the $\mathrm{pDR}$ for gravimetric time-weighted average (TWA) concentrations. pDR concentrations were also humidity corrected using standard approaches [24]. Filters were preconditioned for $24 \mathrm{~h}$ in a humidity and temperature controlled room prior to being weighed in the same room. Indoor PM samples included at least 10\% blanks and duplicates and all reported concentrations were blank corrected.

$\mathrm{CO}_{2}$ and $\mathrm{CO}$ were measured at 1-min intervals using a direct-reading Advanced Sense Pro indoor air quality (IAQ) meter (GrayWolf Sensing Solutions LLC, Shelton, CT, USA). A dual-wave NDIR IR-Infrared sensor was used to measure $\mathrm{CO}_{2}$ while an electromechanical sensor was used to detect CO. The IAQ meter was factory calibrated annually and checked for quality control weekly using a calibration kit provided by the manufacturer for a one point calibration with zero air starting in April 2018. Prior to that only annual calibrations were used. Within each monitoring location, the IAQ meter was placed on a table approximately $1 \mathrm{~m}$ away from the ground and away from air vents, windows, and doors, as possible. Indoor temperature measurements were obtained using HOBO data loggers (HOBO U12 Data Logger, Onset Computer Corporation, Bourne MA, USA). 
Outside of each school, samplers were placed on the roof to assess the contribution of outdoor air to indoor air quality. Outdoor sampling at each school occurred throughout both weeks of indoor air quality monitoring (including the weekend between the two indoor sampling weeks) (mean outdoor visit length: $240.5 \pm 48.9$ h). A SKC Personal Environmental Monitor (PEM) for $\mathrm{PM}_{2.5}$ with the same type of filter used for the $\mathrm{pDR}$ was connected to an Allegro model 9805 diaphragm sampling pump (Allegro Industries, Piedmont, SC, USA), operating at the air flow of $4 \mathrm{~L} / \mathrm{min}$. A battery powered iButton data logger (iButtonLink, Whitewater, WI, USA) was used to measure outdoor temperature at 10-min intervals.

\subsection{Statistical Analysis}

For each monitored location, $\mathrm{CO}_{2}$ and $\mathrm{CO}$ were monitored at 1-min resolution and indoor $\mathrm{PM}_{2.5}$ was monitored at 5-min resolution. For indoor temperature, data were first measured at 10-min intervals and then averaged at the hour level, taking the mean of each hour's six measurements. School day mean values (8 AM to $4 \mathrm{PM}$ ) of $\mathrm{CO}_{2}, \mathrm{PM}_{2.5}, \mathrm{CO}$, and indoor temperature were calculated. During data quality control assessments, $\mathrm{CO}_{2}$ data was filtered to remove values $>4000 \mathrm{ppm}$ and $<250 \mathrm{ppm}$ as a school day mean $(3.9 \%$ of days). The limit of detection was $1 \mu \mathrm{g} / \mathrm{m}^{3}$ for the $\mathrm{PM}_{2.5}$; for school day mean values below the LOD, a value of LOD $/ \sqrt{ } 2\left(0.7 \mu \mathrm{g} / \mathrm{m}^{3}\right)$ was imputed ( $4.6 \%$ of days). CO data was reported at intervals of $1 \mathrm{ppm}$ and was filtered to remove values for which $0 \mathrm{ppm}$ was reported for more than $90 \%$ of the school day ( $27.3 \%$ of days).

For each monitored location, outdoor $\mathrm{PM}_{2.5}$ and temperature were monitored. There was one outdoor sample collected for $\mathrm{PM}_{2.5}$ over the two week period per school, resulting in one value for approximately 12 days of sampling. Outdoor temperature data was measured at 10-min intervals and then averaged at the hour level, taking the mean of each hour's six measurements. School day mean values (8 AM to 4 PM) of outdoor temperature were calculated.

Descriptive statistics (median and interquartile range, IQR) were calculated for all air quality measures prior to and post-renovation. $\mathrm{CO}_{2}$ was compared to an indoor concentration of $1000 \mathrm{ppm}$ as recommended by the American Society of Heating, Refrigerating, and Air Conditioning Engineers (ASHRAE) [25]. $\mathrm{PM}_{2.5}$ and $\mathrm{CO}$ values were compared to corresponding indoor WHO guidelines $\left(25 \mu \mathrm{g} / \mathrm{m}^{3}\right.$ for $\mathrm{PM}_{2.5}$ and $7 \mathrm{mg} / \mathrm{m}^{3}[\sim 6.1 \mathrm{ppm}$ at $25^{\circ} \mathrm{C}$ for $\mathrm{CO}$ ] as a $24 \mathrm{~h}$ average) [26].

For indoor temperature, in addition to describing the average school day value, the proportion of respective temperature measurements taken at $10 \mathrm{~min}$ resolution at each site during the school day that were outside of the recommended value/range based on standards from ASHRAE were calculated prior to and following renovation. For indoor temperature, recommended seasonal temperatures from ASHRAE assume slow air moment and 40\% indoor relative humidity. The recommended indoor temperature ranges are $68-75^{\circ} \mathrm{F}$ or $20-23.9^{\circ} \mathrm{C}$ in fall/winter and $73-80^{\circ} \mathrm{F}$ or $22.8-26.7^{\circ} \mathrm{C}$ in spring/summer $[27,28]$. Temperature measurements were designated as being in range if they were within recommended ASHRAE guidelines based on season of assessment. Temperatures were considered to be too cold or too warm if they were below or above the limit of the ASHRAE recommended range for the season by $4{ }^{\circ} \mathrm{C}$ or less. Extreme values were defined as values that were more than $4{ }^{\circ} \mathrm{C}$ outside of the ASHRAE recommended range (too warm or too cold). The sum of temperature measurements that were assigned as extremely too cold, too cold, too warm, and extremely too warm divided by the total number of temperatures measurements were determined to be the proportion out of range for each school, location, and season.

Within the seven schools with pre- and post-renovation data, we assessed four indoor environmental parameters $\left(\mathrm{CO}_{2}, \mathrm{PM}_{2.5}, \mathrm{CO}\right.$, and proportion of temperature out of range) and two outdoor environmental parameters ( $\mathrm{PM}_{2.5}$ and average school daily temperature) using six separate linear mixed models. Given that we had multiple time points of data measurement nested within each school, and to account for missing data, we used maximum likelihood estimates. Linear mixed models were used to account for intra-cluster 
variance of observations within schools. A mean school daily value of $\mathrm{CO}_{2}$, indoor $\mathrm{PM}_{2.5}$, $\mathrm{CO}$, and a total proportion of temperature out of range from each of the four locations within each school during each visit was included in the model. A mean school daily value of outdoor temperature and a two-week value of outdoor $\mathrm{PM}_{2.5}$ within one location outside of each school was included in the model. $\mathrm{CO}_{2}$, indoor and outdoor $\mathrm{PM}_{2.5}$, and $\mathrm{CO}$ school daily mean values were log-transformed. Each model was controlled for renovation status of the school and season (fall, winter, spring). The results of a similar analysis incorporating all schools within our sample are included in the Online Supplement.

\section{Results}

Prior to renovation, IAQ measures $\left(\mathrm{CO}_{2}, \mathrm{PM}_{2.5}\right.$, and $\left.\mathrm{CO}\right)$ and temperature were measured in 26 schools and post-renovation IAQ measures and temperature were measured in 11 schools. Schools had a median Facility Condition Index (FCI) of 70.6 (IQR: 59.3-91.75), which corresponded to the very poor category. The majority of students were non-white (median 98.8\%; IQR: 92.7-99.1\%) with 93.7\% (IQR: 89.5-96.1\%) of free and reduced lunch meals (FARMS) provided in the 2014-2015 school year. The median year of school construction was 1958, with the oldest school constructed in 1910 and the most recent in 1981. Within the seven schools that had pre- and post-renovation data, the median FCI was 76.4 (IQR: 65.1-96.5), and the median year of construction was 1944 (Table 1).

Table 1. Characteristics of schools.

\begin{tabular}{|c|c|c|c|}
\hline School Statistics & School Variable & No. (\% of 29 Total Schools) & $\begin{array}{l}\text { No. (\% of } 7 \text { Schools with Pre- } \\
\text { and Post- Renovation Data) }\end{array}$ \\
\hline \multirow[t]{4}{*}{ School type } & Elementary school only (K-5) & $10(34.5)$ & $1(14.3)$ \\
\hline & Elementary/Middle school (K-8) & $15(51.7)$ & $3(42.9)$ \\
\hline & Middle/High school & $1(3.4)$ & $1(14.3)$ \\
\hline & High school only & $3(10.3)$ & $2(28.6)$ \\
\hline \multirow[t]{2}{*}{ School renovation status } & Renovated & $9(31)$ & $5(71.4)$ \\
\hline & Replaced & $2(6.8)$ & $2(28.6)$ \\
\hline \multirow[t]{4}{*}{$\begin{array}{l}\text { Stage of renovation that } \\
\text { data was collected }\end{array}$} & Pre-renovation only & $19(65.5)$ & 0 \\
\hline & $\begin{array}{l}\text { Pre-renovation and } \\
\text { Post-renovation }\end{array}$ & $7(24.1)$ & $7(100)$ \\
\hline & Post-renovation only & $3(10.3)$ & 0 \\
\hline & & Median (IQR) & Median (IQR) \\
\hline \multirow[t]{4}{*}{ School characteristics } & Facility condition index ${ }^{a}$ & $70.6(59.3-91.75)$ & $76.4(65.1-96.5)$ \\
\hline & Year of construction & 1958 (Min: 1910/Max: 1981) & 1944 (Min: 1926/Max: 1971) \\
\hline & $\%$ Non-white students $b$ & $98.8(92.7-99.1)$ & $99.1(85.3-99.8)$ \\
\hline & $\%$ Free and reduced lunch ${ }^{c}$ & $93.7(89.5-96.1)$ & $91.3(85.2-94.6)$ \\
\hline
\end{tabular}

a Facility Condition Index (FCI) is an industry standard to evaluate building conditions: $\leq 10 \%$ is good condition; $11-30 \%$ is average; $31-50 \%$ is poor; $51-74 \%$ is very poor; $\geq 75 \%$ is a candidate for replacement. FCI was measured in all schools within the Jacobs Report [21].

b \% Non-white students is the percentage of non-white students within the school during the year of entry in the study [29]. ${ }^{\mathrm{c}} \%$ Free and Reduced Lunch Meals (FARMS) is the percentage of free and reduced meals provided within the school during the 2014-2015 school year. Baltimore City started offering free and reduced meals to all public school students in June 2015 [30].

\subsection{Indoor Air Quality Measures}

Within the seven schools that had pre- and post-renovation data, the median average school daily $\mathrm{CO}_{2}$ was $774.0 \mathrm{ppm}$ (IQR: 626.3-1073.2 ppm), with over $30 \%$ of average school daily $\mathrm{CO}_{2}$ measurements exceeding ASHRAE guidelines. Following renovation, the median average school daily $\mathrm{CO}_{2}$ was $542.4 \mathrm{ppm}$ (IQR: 460.3-679.4 ppm), with over $10 \%$ of average school daily $\mathrm{CO}_{2}$ measurements exceeding ASHRAE guidelines (Table 2). Prior to 
renovation, the median average school daily $\mathrm{PM}_{2.5}$ was $5.9 \mu \mathrm{g} / \mathrm{m}^{3}$ (IQR: $3.8-9.5 \mu \mathrm{g} / \mathrm{m}^{3}$ ) with average school daily $\mathrm{PM}_{2.5}$ exceeding $\mathrm{WHO}$ guidelines $2 \%$ of the time. Following renovation, the median average school daily $\mathrm{PM}_{2.5}$ was $2.7 \mu \mathrm{g} / \mathrm{m}^{3}$ (IQR: $1.4-5.2 \mu \mathrm{g} / \mathrm{m}^{3}$ ) with all average school daily $\mathrm{PM}_{2.5}$ measurements below WHO guidelines. Prior to renovation, the median school daily CO was 0.4 ppm (IQR: $0.3-0.6 \mathrm{ppm}$ ) and all values were within indoor air quality guidelines from the WHO. Following renovation, median average school daily $\mathrm{CO}$ was $0.3 \mathrm{ppm}$ (IQR: $0.1-0.6 \mathrm{ppm}$ ). Indoor air quality metrics within the overall sample of 29 schools were similar to the seven schools with pre- and post-renovation data and are shown in Online Supplement Table S1.

Table 2. Characteristics of indoor and outdoor air quality and performance outcomes by renovation status in 7 schools with pre- and post-renovation data.

\begin{tabular}{|c|c|c|c|c|c|c|c|c|c|c|}
\hline \multirow[b]{2}{*}{ Indoor Exposures } & \multicolumn{5}{|c|}{ Pre-Renovation } & \multicolumn{5}{|c|}{ Post-Renovation } \\
\hline & Season & N1 & $\mathbf{N} 2$ & $\begin{array}{l}\text { Median } \\
\text { (IQR) }\end{array}$ & Min, Max & Season & N1 & $\mathrm{N} 2$ & $\begin{array}{l}\text { Median } \\
\text { (IQR) }\end{array}$ & Min, Max \\
\hline $\begin{array}{l}\text { School daily } \mathrm{CO}_{2} \\
\text { (ppm) }\end{array}$ & & 7 & 230 & $\begin{array}{c}774.0 \\
(626.3-1073.2)\end{array}$ & $354.1,2157.1$ & & 7 & 232 & $\begin{array}{c}542.4 \\
(460.3-679.4)\end{array}$ & $332.2,2444$ \\
\hline $\begin{array}{c}\text { School daily } \mathrm{PM}_{2.5} \\
\left(\mu \mathrm{g} / \mathrm{m}^{3}\right)\end{array}$ & & 7 & 204 & $5.9(3.8-9.5)$ & $1.0,25.5$ & & 7 & 252 & $2.7(1.4-5.2)$ & $0.7,17.9$ \\
\hline $\begin{array}{l}\text { School daily CO } \\
\text { (ppm) }\end{array}$ & & 7 & 209 & $0.4(0.3-0.6)$ & $0,1.4$ & & 7 & 179 & $0.3(0.1-0.6)$ & $0,3.1$ \\
\hline \multirow[t]{3}{*}{$\begin{array}{c}\text { School daily } \\
\text { temperature }\left({ }^{\circ} \mathrm{C}\right)\end{array}$} & Fall & 4 & 41 & $\begin{array}{c}23.5 \\
(21.9-25.5)\end{array}$ & $18.1,28.0$ & Fall & 6 & 95 & $\begin{array}{c}22.5 \\
(21.4-23.5)\end{array}$ & $18.4,26.5$ \\
\hline & Winter & 6 & 67 & $\begin{array}{c}22.2 \\
(20.9-24.8)\end{array}$ & $14.7,27.4$ & Winter & 6 & 78 & $\begin{array}{c}22.2 \\
(21.3-22.9) \\
\end{array}$ & $18.9,25.5$ \\
\hline & Spring & 7 & 94 & $\begin{array}{c}23.3 \\
(21.9-24.9)\end{array}$ & $15.0,28.0$ & Spring & 6 & 54 & $\begin{array}{c}23.4 \\
(22.4-23.9)\end{array}$ & $20.6,24.8$ \\
\hline \multicolumn{11}{|l|}{ Outdoor Exposures } \\
\hline $\begin{array}{c}\text { Two week average } \\
\mathrm{PM}_{2.5}\left(\mu \mathrm{g} / \mathrm{m}^{3}\right)\end{array}$ & & 7 & 18 & $8.0(7.3-14.3)$ & $6.7,56.1$ & & 3 & 8 & $6.7(5.2-7.5)$ & $4.0,8.5$ \\
\hline \multirow[t]{3}{*}{$\begin{array}{c}\text { School daily } \\
\text { temperature }\left({ }^{\circ} \mathrm{C}\right)\end{array}$} & Fall & 4 & 37 & $\begin{array}{c}20.9 \\
(18.4-23.2)\end{array}$ & $7.3,33.6$ & Fall & 4 & 44 & $\begin{array}{c}20.2 \\
(14.9-26.7)\end{array}$ & $1,37.4$ \\
\hline & Winter & 5 & 58 & $8.5(4.2-14.2)$ & $-6.1,23.6$ & Winter & 3 & 29 & $4.9(2.8-8.1)$ & $-4.0,17.0$ \\
\hline & Spring & 6 & 67 & $\begin{array}{c}16.3 \\
(11.6-23.3)\end{array}$ & $4.4,30.7$ & Spring & 4 & 30 & $\begin{array}{c}20.1 \\
(12.5-25.3)\end{array}$ & $8.5,38.3$ \\
\hline
\end{tabular}

$\mathrm{N} 1$ = Number of schools monitored. N2 = Number of days monitored (indoor CO, indoor $\mathrm{CO}_{2}$, indoor $\mathrm{PM}_{2.5}$, indoor temperature, outdoor temperature) or number of two week measurements (outdoor $\mathrm{PM}_{2.5}$ ). All school daily measurements were taken between 8:00 a.m. and to 4:00 p.m.

Box plots of school daily indoor air quality data for schools prior to and post-renovation within the seven schools with pre- and post-renovation data, compared to recommended indoor air quality levels, are shown in Figure 1.

The results of the linear mixed models for indoor air quality within the seven schools with pre- and post-renovation data, shown in Table 3, show significant reductions in $\mathrm{CO}_{2}$, indoor $\mathrm{PM}_{2.5}$, and $\mathrm{CO}$ by renovation status after controlling for season. Linear mixed models of indoor air quality within the full sample of 26 pre-renovation and 11 post-renovation schools show similar results (Online Supplement Table S2). 


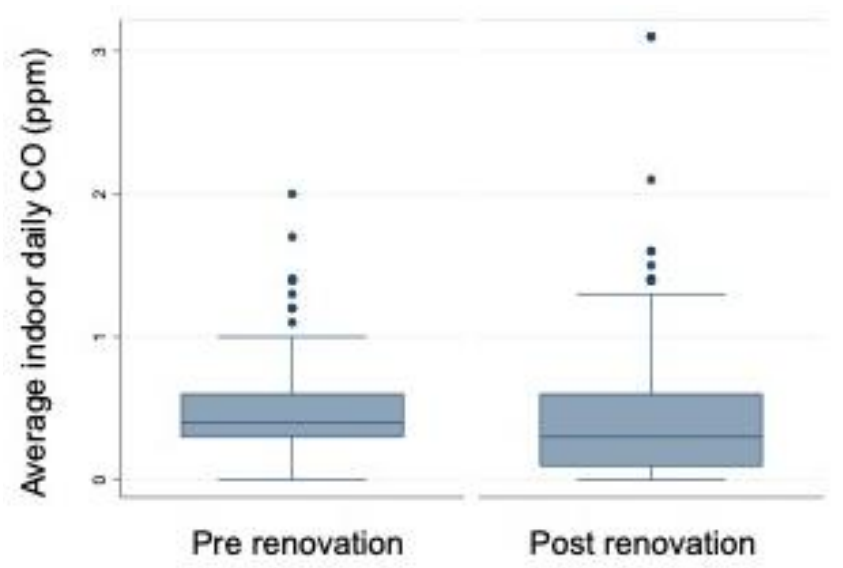

(A)

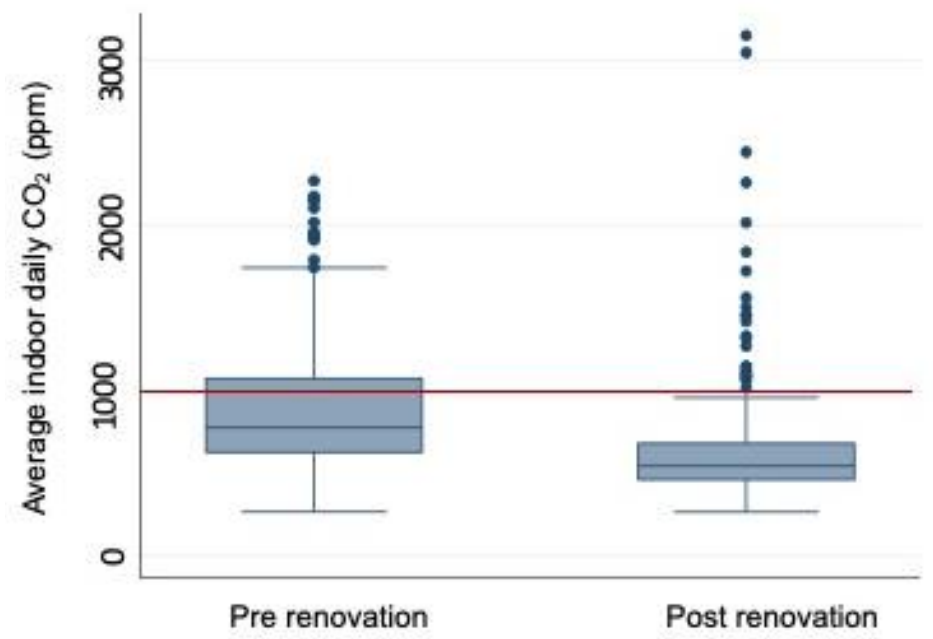

(B)

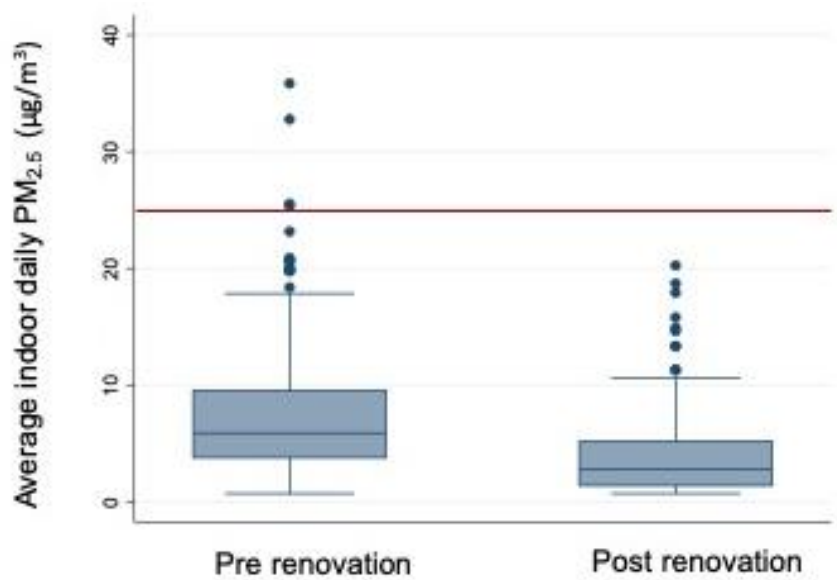

(C)

Figure 1. Indoor air quality measures by school renovation status in seven schools with pre- and post-renovation data. The boxes demonstrate the interquartile range (IQR) of the indoor air quality measure. Whiskers represent closest value within $1.5 \times$ the IQR of the indoor air quality measure. Blue dots represent individual values that extend beyond the whisker value. The red line in (B) represents the indoor concentration of $1000 \mathrm{ppm}$ recommended by ASHRAE. The red line in (C) represents the indoor WHO guidelines of $25 \mu \mathrm{g} / \mathrm{m}^{3}$. All CO values were below the recommended 
WHO guideline of $7 \mathrm{mg} / \mathrm{m}^{3}\left(6.1 \mathrm{ppm}\right.$ at $\left.25^{\circ} \mathrm{C}\right)$. All school daily measurements included were taken between 8:00 a.m. and 4:00 p.m. (A) Indoor school daily CO by school renovation status; (B) Indoor school daily $\mathrm{CO}_{2}$ by school renovation status; (C) Indoor school daily $\mathrm{PM}_{2.5}$ by school renovation status.

Table 3. Linear mixed models comparing indoor air quality within seven schools with pre- and post-renovation monitoring data.

\begin{tabular}{ccccc}
\hline Indoor Exposures & Coefficient & 95\% CI LB & 95\% CI UB & $p$ Value \\
\hline Log school daily average $\mathrm{PM}_{2.5}$ & -0.789 & -0.947 & -0.630 & $<0.05$ \\
\hline Log school daily average CO & -0.296 & -0.472 & -0.120 & $<0.001$ \\
\hline Log school daily average $\mathrm{CO}_{2}$ & -0.345 & -0.420 & -0.269 & $<0.001$ \\
\hline Proportion of Temperature out of Range & -0.214 & -0.318 & -0.110 & 0.435 \\
\hline Outdoor Exposures & & & \\
\hline Log $\mathrm{PM}_{2.5}$ & -0.467 & -0.860 & -0.075 & $\mathrm{NS}$ \\
\hline School daily temperature & 0.0273 & -2.01 & 2.06 & $<0.001$ \\
\hline
\end{tabular}

Note: $\mathrm{PM}_{2.5}, \mathrm{CO}$, and $\mathrm{CO}_{2}$ have been log transformed. This model controls for season and renovation status Coefficient values are comparing post-renovation to pre-renovation status, resulting in negative values for the environmental measures that suggest improvement. School daily exposure measurements were taken between 8:00 a.m. and 4:00 p.m. The abbreviation NS stands for not significant.

\subsection{Indoor Air Temperature and Temperature out of Range}

Within the seven schools with pre- and post-renovation data, there was decreased temperature variability across seasons following renovation (Table 2, Figure 2). The results of the linear mixed model, in Table 3, show a reduction of proportion of temperature out of range by $21 \%$ following renovation after controlling for season. Results of the linear mixed model including all schools in the sample were similar, with a significant reduction in proportion of temperature out of range by 19\% (Online Supplement Table S2).

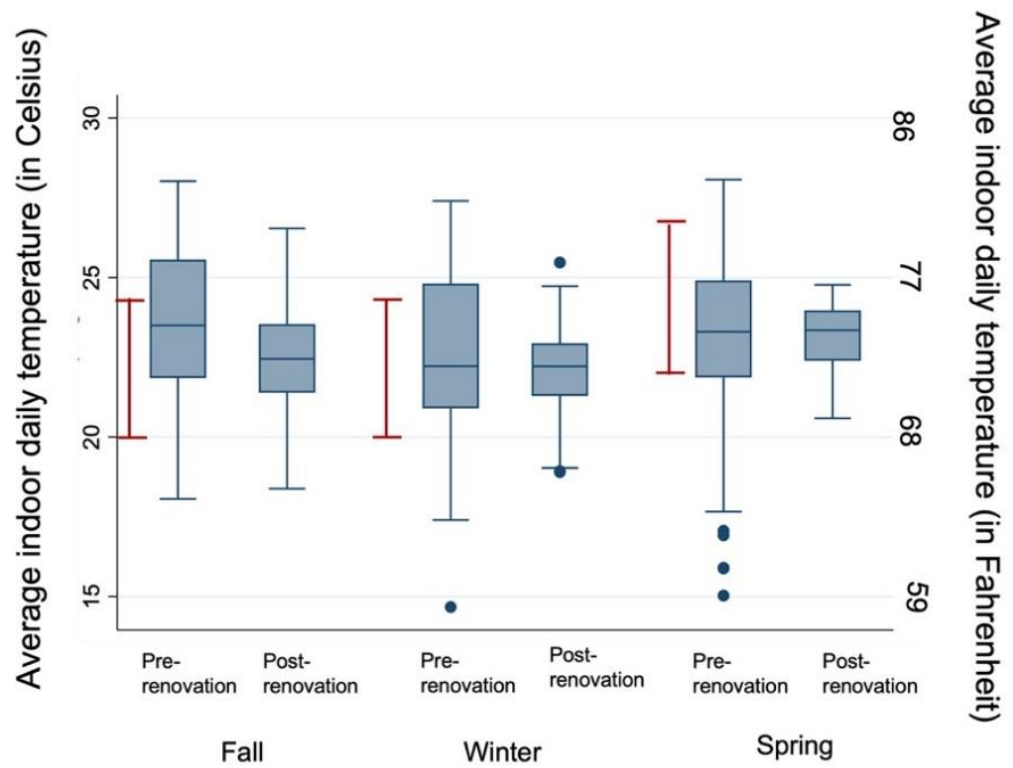

Figure 2. Indoor school daily temperature by school renovation status and season in seven schools with pre- and post-renovation data. The boxes demonstrate the IQR of average indoor daily temperature. Whiskers represent closest value within $1.5 \times$ the IQR of the average indoor daily temperature. Blue dots represent individual values that extend beyond the whisker values. Red lines indicate recommended indoor temperature guidelines from ASHRAE: $68-75^{\circ} \mathrm{F}\left(20-23.9^{\circ} \mathrm{C}\right)$ in fall/winter and $73-80^{\circ} \mathrm{F}\left(22.8-26.7^{\circ} \mathrm{C}\right)$ in the spring/summer. Indoor school daily temperatures were measured between 8:00 a.m. and 4:00 p.m. 
The proportion of indoor air temperatures out of range, by season, prior to and following renovation is shown in Figure 3 (temperature measured every $10 \mathrm{~min}$ ). Temperatures were more frequently within the recommended range following renovation $(72.0 \%)$ than prior to renovation $(49.4 \%)$. Prior to renovation, temperatures were too warm $39.6 \%$ of the time in the fall, $27.9 \%$ of the time in the winter, and $9.3 \%$ of the time in the spring. Additionally prior to renovation, temperatures were extremely too warm $6.8 \%$ of the time in the fall, $1.9 \%$ of the time in the winter, and $0.2 \%$ of the time in the spring. Following renovation, $21.3 \%$ of temperatures were too warm in the fall, $10.5 \%$ were too warm in the winter, and $0.6 \%$ were too warm in the spring. Following renovation, there was improvement in indoor temperature such that no temperatures were extremely too warm in the fall or spring and only $0.5 \%$ of temperatures were extremely too warm in the winter.

Pre Renovation

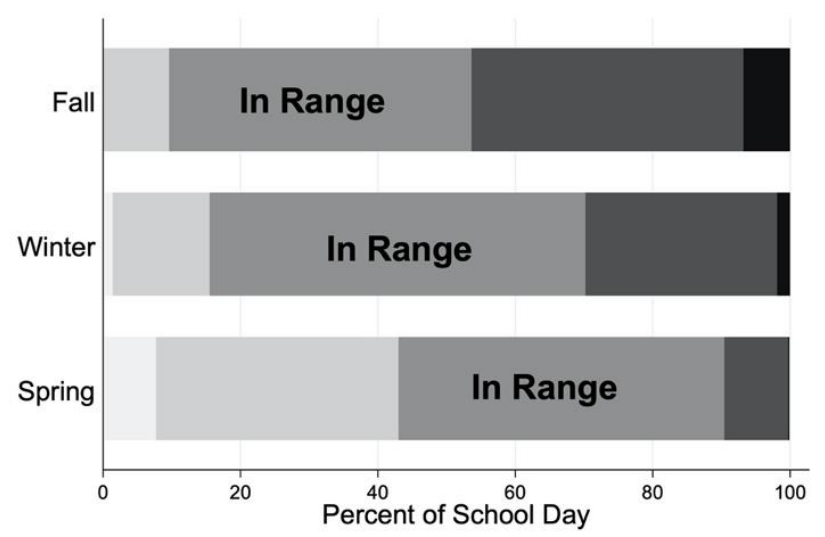

Post Renovation

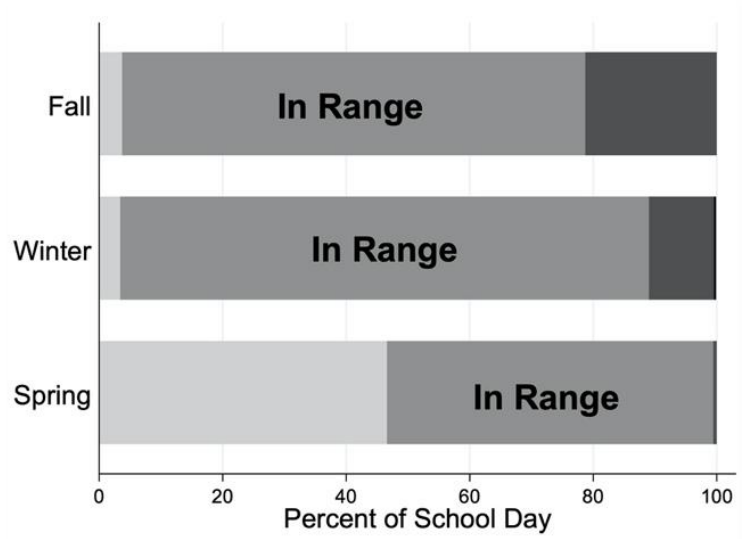

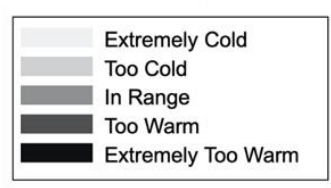

Figure 3. Proportion of indoor temperatures within and outside of range in seven schools with pre- and post-renovation monitoring data. In range indoor air temperatures were determined according to ASHRAE guidelines by season: $68-75^{\circ} \mathrm{F}$ $\left(20-23.9^{\circ} \mathrm{C}\right)$ in fall/winter and $73-80^{\circ} \mathrm{F}\left(22.8-26.7^{\circ} \mathrm{C}\right)$ in the spring/summer. Temperatures were considered to be too cold or too warm if they were below or above the limit of the ASHRAE recommended range for the season by $4{ }^{\circ} \mathrm{C}$ or less. Extreme values were defined as values that were more than $4{ }^{\circ} \mathrm{C}$ outside of the ASHRAE recommended range. All indoor temperatures included were taken during the school day, between 8:00 a.m. and 4:00 p.m.

Prior to renovation, temperatures were too cold $9.6 \%$ of the time in the fall, $14.1 \%$ of the time in the winter, and $35.3 \%$ of the time in the spring. Additionally prior to renovation, temperatures were extremely too cold $1.4 \%$ of the time in the winter and $7.8 \%$ of the time in the spring. Following renovation, $3.7 \%$ of temperatures were too cold in the fall, $3.4 \%$ were too cold in the winter, and $46.6 \%$ were too cold in the spring. Also, following renovation, there was improvement such that no temperatures were extremely too cold in the fall, winter, or spring. The proportion of indoor air temperatures out of range by season in the complete sample of 29 schools can be seen in Online Supplement Figure S1.

\subsection{Outdoor Air Quality Measures}

Prior to renovation, the two week average outdoor $\mathrm{PM}_{2.5}$ was $8.0 \mu \mathrm{g} / \mathrm{m}^{3}$ (IQR: 7.3$14.3 \mu \mathrm{g} / \mathrm{m}^{3}$ ) and following renovation, it was $6.7 \mu \mathrm{g} / \mathrm{m}^{3}$ (IQR: $5.2-7.5 \mu \mathrm{g} / \mathrm{m}^{3}$ ). Prior to renovation, median school daily temperature was $20.9^{\circ} \mathrm{C}$ (IQR: $18.3-23.2^{\circ} \mathrm{C}$ ) in the fall, $8.5^{\circ} \mathrm{C}$ (IQR: $4.2-14.2{ }^{\circ} \mathrm{C}$ ) in the winter, and $16.3^{\circ} \mathrm{C}$ (IQR: $11.6-23.3^{\circ} \mathrm{C}$ ) in the spring. Following renovation, median school daily temperature was $20.2^{\circ} \mathrm{C}$ (IQR: $14.9-26.7^{\circ} \mathrm{C}$ ) in the fall, $4.9^{\circ} \mathrm{C}$ (IQR: 2.8-8.1 ${ }^{\circ} \mathrm{C}$ ) in the winter, and $20.1^{\circ} \mathrm{C}$ (IQR: $12.5-25.3^{\circ} \mathrm{C}$ ) in the spring (Table 2). 
The results of the linear mixed models for outdoor air quality (Table 3) showed no difference in outdoor $\mathrm{PM}_{2.5}$ by renovation status after controlling for season, and significantly warmer temperatures following renovation compared to prior to renovation.

\section{Discussion}

A school renovation program in an urban, mid-Atlantic school district provided the opportunity to apply a natural experimental design to study the impact of building renovation or replacement on indoor air quality. Prior to renovation, within the seven schools in our sample that had pre- and post-renovation data, nearly one third of indoor $\mathrm{CO}_{2}$ measurements exceeded recommended guidelines, and over half of indoor temperature measurements were outside of the recommended range, typically too warm even when temperatures were cool outside. All CO and most $\mathrm{PM}_{2.5}$ levels fell within recommended guidelines prior to renovation. Following school renovation, there were improvements in indoor air quality with a significant decrease in $\mathrm{CO}_{2}$, indoor $\mathrm{PM}_{2.5}$, and $\mathrm{CO}$ levels, in addition to an improvement in indoor temperature more frequently within the recommended range for thermal comfort.

The study addresses a recognized research gap by intensively characterizing school indoor air quality with direct assessment at multiple times across different seasons. The unique design provided the opportunity to quantify the impact of an intervention-school renovation or replacement-on indoor air quality. The study was based in an urban school district that serves predominantly low-income, Black children who are disproportionately affected by challenges of aging school infrastructure in urban areas across the United States [31]. The 2011 survey that informed the school renovation program upon which this study was based reported that nearly a quarter of schools were constructed before 1946 $(23 \%)$, and that the majority (122 out of 145$)$ were rated in poor or worse condition. Only 1 of the 145 schools surveyed was rated in good condition [21]. It is also notable that the schools that were slated to undergo renovation first were those in the worst condition and thus are the schools included in the present study.

Our data shows substantial post-renovation improvement in ventilation, which refers to the exchange of indoor air for clean outdoor air in order to dilute air pollution or contaminants that come from indoor sources and the crowding of people. Notably, among our larger sample of 26 schools that had pre-renovation measurements, more than onequarter had median $\mathrm{CO}_{2}$ values that exceeded the ASHRAE recommended threshold, and this was substantially improved among schools that underwent renovation. Most schools and buildings have HVAC systems with filters on them to maintain good indoor air quality and to provide thermal comfort. In general, the greater number of people in an indoor space, the greater need for ventilation, and thus $\mathrm{CO}_{2}$ is used as a surrogate for adequacy of ventilation per occupant. Elevated $\mathrm{CO}_{2}$ has been associated with reduced student performance in several states and many countries [19,32-35], and also associated with an increase in student absences in the US [36]. Marked improvement in ventilation after renovation demonstrates the benefit of investment in school infrastructure with improvement in ventilation, which has the potential to improve standardized test scores and academic performance [34,35], reduce respiratory health effects, and reduce student absences [34]. Of note, in the context of the current SARS-CoV-2 pandemic, there has been increased attention to ventilation characteristics of school buildings. In devising plans to allow children to return to school safely, improving ventilation is one strategy that is being promoted to mitigate airborne viral transmission as well as to improve indoor air quality.

Within the seven schools with pre- and post-renovation data, the majority of baseline average indoor $\mathrm{PM}_{2.5}$ concentrations (median $5.9 \mu \mathrm{g} / \mathrm{m}^{3}$, IQR: $3.8-9.5 \mu \mathrm{g} / \mathrm{m}^{3}$ ) were below the recommended limits for indoor air and consistent with the few other studies that have assessed indoor PM in school environments [37]. $\mathrm{PM}_{2.5}$ measured in schools was much lower than $\mathrm{PM}_{2.5}$ that have been measured in homes of children in an urban environment in several other research studies [7,38-40]. One contributing factor to lower $\mathrm{PM}_{2.5}$ levels in schools may be the lack of secondhand smoke (SHS), which is a prominent contributor to 
household $\mathrm{PM}_{2.5}$. SHS was initially assessed within this study but was discontinued, as it was found to be routinely below the limit of detection $(90 \%$ of collected samples below the limit of detection). School policies ban smoking on campus and study staff did not observe any evidence of smoking on campus over the study period.

While there were improvements in indoor $\mathrm{PM}_{2.5}$ concentrations with renovation, there was no change in concurrently measured outdoor $\mathrm{PM}_{2.5}$ concentrations over time, suggesting that improvements in indoor $\mathrm{PM}_{2.5}$ were not due to changes in outdoor levels. Despite low baseline $\mathrm{PM}_{2.5}$ values, school renovation still resulted in reductions of $\mathrm{PM}_{2.5}$ concentrations. This is notable due to evidence suggesting that reduction of $\mathrm{PM}_{2.5}$, even at lower concentrations, may have amplified health benefits, and that there is no evidence of a threshold value, meaning that lower PM is better and there is no safe level of exposure below which there is not the potential for adverse health effects [41,42]. This may be especially relevant for children who have higher respiratory rates and are developing physically (e.g., lung growth, neurocognition) [43].

Thermal comfort was assessed and baseline findings were striking and mirrored the experiences of the study staff regarding the proportion of time that temperature was beyond that in the range for thermal comfort. The extreme values measured were informative. For example, within schools with pre and post renovation data, temperatures were too warm or extremely too warm $46.4 \%$ and $29.8 \%$ of the time during the fall and winter prior to renovation. There were no extremely too warm values measured post-renovation. It is logical that such thermal conditions may not be conducive to optimal learning. Prior data has shown that indoor temperatures impact student achievement with classroom temperature reduced to the lower end of the comfortable range being associated with increased student work rate, reduced errors, and higher performance scores [20,44]. Higher classroom temperatures have also been shown to be associated with higher daytime attacks of breathlessness [33]. Our findings suggest that renovation greatly improves temperature control with over $20 \%$ improvement in the number of days within recommended ranges following school renovation. Perhaps surprisingly, the temperatures were still out of range $28 \%$ of the time following renovation, with more temperatures out of range being too cold rather than too warm. This could be due to incomplete benefit of the renovation on the goal of achieving climate control or, alternately, may be due to factors such as the scheduled programming of thermostats that are not responsive to real time weather changes (e.g., heat is turned off in the spring overnight or not turned back on during unexpected cold weather events).

There were several limitations to this study. Given that this study occurred within a natural experiment of an ongoing urban school renovation project and schools were selected based on poor condition, we were unable to randomly assign renovation status to schools within the district or control the extent of renovation performed. The planned renovation timeline for schools extends beyond our study window and thus we sampled more schools pre-renovation than post-renovation. As the renovation project was based in urban schools with low income and minority students, findings may be representative of similar low income communities throughout the country, but are not generalizable to all schools. However, the improvement of indoor school air quality for this vulnerable group of students is particularly important due to known disparities in health and education among low-income communities. Additionally, individual consent from students, teachers, and staff was not a feature of this study. This was intentional in order to reduce burden on the schools and in order to build a working relationship to foster future collaboration. Thus, we were unable to measure individual benefits for these groups. As cost is a significant consideration of school renovation and replacement, cost analysis is also of great interest but is beyond the scope of this study. Measurements of indoor air quality were measured using electrochemical $(\mathrm{CO})$ and NDIR $\left(\mathrm{CO}_{2}\right)$ sensors. These sensors were selected to provide high temporal resolution data enabling an assessment of concentrations during school hours only. However, these sensors can be less accurate and precise than cumulative methods and can be subject to bias based on environmental conditions. Finally, classroom 
occupancy, which would contribute to ventilation, was not directly measured in this study. As classroom occupancy rates are mandated by school district, occupancy was likely stable prior to and following school renovation.

Due to a history of underinvestment, low income communities have aging school infrastructure that is in significant need of renovation [45]. There is a need to prioritize renovation and replacement of schools within these communities to help address disparities. Our findings show significant improvement in indoor air quality, including $\mathrm{CO}_{2}$, indoor $\mathrm{PM}_{2.5}$, and $\mathrm{CO}$, as well as an increase in the proportion of indoor temperatures within recommended ranges following school renovation. These findings underscore the need for investment in school renovation to improve building infrastructure and indoor air quality, which may lead to health and academic benefits for students and teachers. Future studies should consider measuring the impact of school renovation and improvements in indoor air quality on student health and performance outcomes.

Supplementary Materials: The following are available online at https:/ /www.mdpi.com/article/10 $.3390 /$ ijerph182212149/s1, Figure S1: Proportion of indoor temperatures within and outside of range prior to and post-renovation in 29 schools, Table S1: Characteristics of indoor and outdoor air quality and performance outcomes by renovation status in 29 schools, Table S2: Six linear mixed models showing indoor and outdoor air quality prior to and following school renovation in 29 schools.

Author Contributions: Conceptualization, K.K., M.F.D. and M.C.M.; Methodology, S.E.Z., M.N.E., T.E. and M.C.M.; Software: K.K., T.G. and M.W.; Validation, K.K., T.G. and M.W.; Formal Analysis, S.E.Z., T.E., M.N.E. and M.W.; Data Curation, S.E.Z., K.K., M.W. and T.E.; Writing-Original Draft Preparation, S.E.Z.; Writing-Review \& Editing, S.E.Z., K.K., M.N.E., C.W., I.D., T.D.W., D.C.-E., C.E.G., T.G., E.M., M.L.S., A.R., M.F.D. and M.C.M.; Visualization, K.K., C.W., I.D., M.F.D. and M.C.M.; Supervision, M.N.E., K.K., M.C.M.; Project Administration, D.C.-E.; Funding Acquisition, K.K., M.F.D. and M.C.M. All authors have read and agreed to the published version of the manuscript.

Funding: This publication was developed under Assistance Agreement No 83563901 and 83615201 awarded by the U.S. Environmental Protection Agency (EPA) to Meredith McCormack. Research reported in this publication was supported by National Institute of Environmental Health Sciences of the National Institutes of Health (NIH) under award number P50ES018176. Portions of this work were supported by a Johns Hopkins Spark Award (Ex-SP-09-19003) from the Bloomberg American Health Initiative. MFD was supported by the NIH/Office of the Director (K01OD019918). TDW is supported by the Department of Veterans Affairs, Veterans Health Administration, Office of Research and Development, Center for Innovations in Quality, Effectiveness, and Safety (CIN 13-413). SZ was supported by NIH F32HL149195-01 and NIH T32HL007534-6. This publication has not been formally reviewed by EPA or the US Department of Veterans Affairs. The views expressed in this document are solely those of the authors and do not necessarily reflect those of the EPA or the US Department of Veterans Affairs. EPA does not endorse any products or commercial services mentioned in this publication.

Institutional Review Board Statement: Institutional review board (IRB) approvals were obtained from the Johns Hopkins School of Public Health IRB and the IRB of the participating school district.

Informed Consent Statement: Not applicable.

Data Availability Statement: The data presented in this study are available on request from the corresponding author. The data are not publicly available due to potential identification.

Conflicts of Interest: The authors declare that they have no actual or potential competing interest.

\section{References}

1. U.S. Environmental Protection Agency. Report to Congress on Indoor Air Quality: Volume 2; EPA/400/1-89/001C; U.S. Environmental Protection Agency: Washington, DC, USA, 1989.

2. Breysse, P.N.; Diette, G.B.; Matsui, E.C.; Butz, A.M.; Hansel, N.N.; McCormack, M.C. Indoor Air Pollution and Asthma in Children. Proc. Am. Thorac. Soc. 2010, 7, 102-106. [CrossRef] [PubMed]

3. Annesi-Maesano, I.; Baiz, N.; Banerjee, S.; Rudnai, P.; Rive, S.; on behalf of the SINPHONIE Group. Indoor Air Quality and Sources in Schools and Related Health Effects. J. Toxicol. Environ. Health Part B 2013, 16, 491-550. [CrossRef] [PubMed] 
4. Bluyssen, P.M. Health, Comfort and Performance of Children in Classrooms-New Directions for Research: Indoor Built Environ. Available online: https:/ /journals.sagepub.com/doi/10.1177/1420326X16661866 (accessed on 5 August 2016).

5. Mendell, M.J.; Heath, G.A. Do indoor pollutants and thermal conditions in schools influence student performance? A critical review of the literature. Indoor Air 2005, 15, 27-52. [CrossRef]

6. Reisman, R.E.; Mauriello, P.M.; Davis, G.B.; Georgitis, J.W.; DeMasi, J.M. A double-blind study of the effectiveness of a highefficiency particulate air (HEPA) filter in the treatment of patients with perennial allergic rhinitis and asthma. J. Allergy Clin. Immunol. 1990, 85, 1050-1057. [CrossRef]

7. Butz, A.M.; Matsui, E.C.; Breysse, P.; Curtin-Brosnan, J.; Eggleston, P.; Diette, G.; Williams, D.; Yuan, J.; Bernert, J.T.; Rand, C. A randomized trial of air cleaners and a health coach to improve indoor air quality for inner-city children with asthma and secondhand smoke exposure. Arch. Pediatr. Adolesc. Med. 2011, 165, 741-748. [CrossRef]

8. Maloney, J.; Sicherer, S.H. Results of a Home-Based Environmental Intervention Among Urban Children With Asthma. Pediatrics 2005, 116 (Suppl. 2), 543. [CrossRef]

9. American Society of Civil Engineers. Infrastructure Report Card. 2017. Available online: https:/ /www.infrastructurereportcard. org/wp-content/uploads/2016/10/2017-Infrastructure-Report-Card.pdf (accessed on 22 October 2020).

10. Cheng, G.; English, S.; Filardo, M. Evidence and Recommendations Concerning the Impact of School Facilities on Civil Rights and Student Achievement. Submission to the US Department of Education Excellence and Equity Commission. Available online: http:/ / www.21csf.org/csf-home/pub.asp (accessed on 17 November 2021).

11. Berman, J.D.; McCormack, M.C.; Koehler, K.A.; Connolly, F.; Clemons-Erby, D.; Davis, M.F.; Gummerson, C.; Leaf, P.J.; Jones, T.D.; Curriero, F.C. School environmental conditions and links to academic performance and absenteeism in urban, mid-Atlantic public schools. Int. J. Hyg. Environ. Health 2018, 221, 800-808. [CrossRef]

12. Majd, E.; McCormack, M.; Davis, M.; Curriero, F.; Berman, J.; Connolly, F.; Leaf, P.; Rule, A.; Green, T.; Clemons-Erby, D.; et al. Indoor air quality in inner-city schools and its associations with building characteristics and environmental factors. Environ. Res. 2019, 170, 83-91. [CrossRef] [PubMed]

13. US EPA. Renovation and Repair, Part of Indoor Air Quality Design Tools for Schools. 2014. Available online: https://www.epa. gov/iaq-schools/renovation-and-repair-part-indoor-air-quality-design-tools-schools (accessed on 8 November 2021).

14. Permaul, P.; Phipatanakul, W. School Environmental Intervention Programs. J. Allergy Clin. Immunol. Pract. 2018, 6, 22-29. [CrossRef] [PubMed]

15. About 21st Century Schools—Baltimore. Available online: https:/ / baltimore21stcenturyschools.org/about (accessed on 7 July 2020).

16. Fan, J.; Li, S.; Fan, C.; Bai, Z.; Yang, K. The impact of $\mathrm{PM}_{2.5}$ on asthma emergency department visits: A systematic review and meta-analysis. Environ. Sci. Pollut. Res. Int. 2016, 23, 843-850. [CrossRef] [PubMed]

17. Mullen, C.; Grineski, S.E.; Collins, T.W.; Mendoza, D.L. Effects of $\mathrm{PM}_{2.5}$ on Third Grade Students' Proficiency in Math and English Language Arts. Int. J. Environ. Res. Public Health 2020, 22, 17. [CrossRef]

18. Townsend, C.L.; Maynard, R.L. Effects on health of prolonged exposure to low concentrations of carbon monoxide. Occup. Environ. Med. 2002, 59, 708-711. [CrossRef] [PubMed]

19. Haverinen-Shaughnessy, U.; Shaughnessy, R.J.; Cole, E.C.; Toyinbo, O.; Moschandreas, D.J. An assessment of indoor environmental quality in schools and its association with health and performance. Build. Environ. 2015, 93, 35-40. [CrossRef]

20. Wargocki, P.; Wyon, D.; Matysiak, B.; Irgens, S. The Effects of Classroom Air Temperature and Outdoor Air Supply Rate on the Performance of School Work by Children. In Proceedings of the 10th International Conference on Indoor Air Quality and Climate, Beijing, China, 4-9 September 2005; pp. 368-372.

21. Jacobs Report: State of School Facilities Baltimore City Public Schools. June 2012. Available online: https://baltimore2 1stcenturyschools.org/about/history (accessed on 9 June 2021).

22. Baltimore City Public Schools' 10-Year Plan. Center on Reinventing Public Education. Available online: https://www.crpe.org/ external-resources / baltimore-city-public-schools-10-year-plan (accessed on 9 June 2021).

23. School Projects. 21st Century Schools-Baltimore. Available online: http://baltimore21stcenturyschools.org/projects (accessed on 8 July 2020).

24. Soneja, S.; Chen, C.; Tielsch, J.M.; Katz, J.; Zeger, S.L.; Checkley, W.; Curriero, F.C.; Breysse, P.N. Humidity and Gravimetric Equivalency Adjustments for Nephelometer-Based Particulate Matter Measurements of Emissions from Solid Biomass Fuel Use in Cookstoves. Int. J. Environ. Res. Public Health 2014, 11, 6400-6416. [CrossRef] [PubMed]

25. Standard 62.1-2019-American Society of Heating, Refrigerating and Air-Conditioning Engineers. Available online: https: / / ashrae.iwrapper.com/ASHRAE_PREVIEW_ONLY_STANDARDS/STD_62.1_2019 (accessed on 5 October 2020).

26. WHO Guidelines for Indoor Air Quality: Selected Pollutants. World Health Organization Regional Office for Europe, 2010. Available online: https:/ / apps.who.int/iris/handle/10665/260127 (accessed on 5 October 2020).

27. Standard 55-2020-American Society of Heating, Refrigerating and Air-Conditioning Engineers. Available online: https: / / ashrae.iwrapper.com/ASHRAE_PREVIEW_ONLY_STANDARDS/STD_55_2020 (accessed on 2 March 2021).

28. US Environmental Protection Agency. Indoor Air Quality Tools for Schools Reference Guide. EPA 402/K-07/008; January 2009. Available online: https://www.epa.gov/indoor-air-quality-iaq/publications-about-indoor-air-quality (accessed on 8 March 2021). 
29. ELSI-Elementary and Secondary Information System. Available online: https://nces.ed.gov/ccd/elsi/expressTables.aspx (accessed on 5 February 2021).

30. MSDE. Maryland Report Card-DataDownloads-Datadownload. Available online: https://reportcard.msde.maryland.gov/ Graphs/\#/DataDownloads/datadownload/3/17/6/99/XXXX (accessed on 5 February 2021).

31. Baltimore City Public Schools Infrastructure Dashboard-JHU Center for Applied Public Research. Available online: https: / / appliedresearch.jhu.edu/baltimore-school-equity / (accessed on 29 December 2020).

32. Daisey, J.M.; Angell, W.J.; Apte, M.G. Indoor air quality, ventilation and health symptoms in schools: An analysis of existing information. Indoor Air 2003, 13, 53-64. [CrossRef] [PubMed]

33. Mi, Y.-H.; Norbäck, D.; Tao, J.; Mi, Y.-L.; Ferm, M. Current asthma and respiratory symptoms among pupils in Shanghai, China: Influence of building ventilation, nitrogen dioxide, ozone, and formaldehyde in classrooms. Indoor Air 2006, 16, 454-464. [CrossRef] [PubMed]

34. Fisk, W.J. The ventilation problem in schools: Literature review. Indoor Air 2017, 27, 1039-1051. [CrossRef]

35. Haverinen-Shaughnessy, U.; Moschandreas, D.J.; Shaughnessy, R.J. Association between substandard classroom ventilation rates and students' academic achievement. Indoor Air 2011, 21, 121-131. [CrossRef] [PubMed]

36. Shendell, D.G.; Prill, R.; Fisk, W.J.; Apte, M.G.; Blake, D.; Faulkner, D. Associations between classroom $\mathrm{CO}_{2}$ concentrations and student attendance in Washington and Idaho. Indoor Air 2004, 14, 333-341. [CrossRef]

37. Carrion-Matta, A.; Kang, C.-M.; Gaffin, J.M.; Hauptman, M.; Phipatanakul, W.; Koutrakis, P.; Gold, D.R. Classroom indoor PM2.5 sources and exposures in inner-city schools. Environ. Int. 2019, 131, 104968. [CrossRef]

38. Diette, G.B.; Hansel, N.N.; Buckley, T.J.; Curtin-Brosnan, J.; Eggleston, P.A.; Matsui, E.C.; McCormack, M.C.; Williams, D.L.; Breysse, P.N. Home Indoor Pollutant Exposures among Inner-City Children With and Without Asthma. Environ. Health Perspect. 2007, 115, 1665-1669. [CrossRef]

39. Brigham, E.P.; Woo, H.; McCormack, M.; Rice, J.; Koehler, K.; Vulcain, T.; Wu, T.; Koch, A.; Sharma, S.; Kolahdooz, F.; et al. Omega-3 and Omega-6 Intake Modifies Asthma Severity and Response to Indoor Air Pollution in Children. Am. J. Respir. Crit. Care Med. 2019, 199, 1478-1486. [CrossRef] [PubMed]

40. McCormack, M.C.; Breysse, P.N.; Matsui, E.C.; Hansel, N.N.; Williams, D.; Curtin-Brosnan, J.; Eggleston, P.; Diette, G.B.; Center for Childhood Asthma in the Urban Environment. In-Home Particle Concentrations and Childhood Asthma Morbidity. Environ. Health Perspect. 2009, 117, 294-298. [CrossRef] [PubMed]

41. Di, Q.; Wang, Y.; Zanobetti, A.; Wang, Y.; Koutrakis, P.; Choirat, C.; Dominici, F.; Schwartz, J.D. Air Pollution and Mortality in the Medicare Population. N. Engl. J. Med. 2017, 376, 2513-2522. [CrossRef] [PubMed]

42. Cromar, K.R.; Gladson, L.A.; Ewart, G. Trends in Excess Morbidity and Mortality Associated with Air Pollution above American Thoracic Society-Recommended Standards, 2008-2017. Ann. Am. Thorac. Soc. 2019, 16, 836-845. [CrossRef]

43. State of the Air. American Lung Association. Available online: https://www.stateoftheair.org/ (accessed on 29 December 2020).

44. Haverinen-Shaughnessy, U.; Shaughnessy, R.J. Effects of Classroom Ventilation Rate and Temperature on Students' Test Scores. PLoS ONE 2015, 10, e0136165. Available online: https:/ / www.ncbi.nlm.nih.gov/pmc/articles/PMC4552953/ (accessed on 17 September 2020). [CrossRef]

45. Huang, C.-C.; Taylor, R. Any Federal Infrastructure Package Should Boost Investment in Low-Income Communities; Center on Budget and Policy Priorities, 28 June 2019. Available online: https:/ / www.cbpp.org/research/federal-budget/any-federal-infrastructurepackage-should-boost-investment-in-low-income (accessed on 9 June 2021). 